\title{
Choice of Locations by Foreign Investors: Motives for and Factors of Starting a Manufacturing Activity (the Example of Selected Factories in Poland)
}

\begin{abstract}
The choice of a location is one of the most important decisions taken by an enterprise, both at start-up and at other stages of its life cycle involving a relocation of activity or a spatial fragmentation of the chain of value-added generation. The choice of a location by an enterprise is also of great significance for the development of the region selected, its economic and social structure, and the pattern of its spatial links. That is what makes the choice of a location one of major research problems in socio-economic geography, and in particular in its sub-discipline - industrial geography, with its scope of research embracing issues in location theory and factors of the location of enterprises and industrial plants.

This paper offers an analysis of the location factors of selected factories - affiliates of international corporations, in terms of their strategic decisions of expansion onto markets abroad in the form of foreign direct investment (FDI). For international corporations, the choice of a new place of economic activity is closely connected with global advantages of conducting business at the international scale and with motives for their internationalisation.
\end{abstract}

Key words: decisions; international corporations; location factors

\section{Choice of A LOCATION AS A RESEARCH PROBLEM OF INDUSTRIAL GEOGRAPHY}

The choice of a location is one of the most important decisions taken by an enterprise, both at start-up and at other stages of its life cycle involving a relocation of activity or a spatial fragmentation of the chain of value-added generation. The choice of a location by an enterprise is also of great significance for the development of the region selected, its economic and social structure, and the pattern of its spatial links. That is what makes the choice of a location one of the major research problems in socio-economic geography, and in particular in its sub-discipline - industrial geography, with its scope of research embracing issues in location theory and factors of the location of enterprises and industrial plants.

In the classical approach to the theory of the location of industry presented by Launhardt (1882) and developed by Weber (1909), the choice of a location was examined with reference to a single enterprise. It was assumed that this should be an optimum choice in terms of 
the minimisation of production costs, and this, in the free-market economy of the early $20^{\text {th }}$ century, meant primarily the choice of a place ensuring minimum transport costs. Since then, however, location theory has evolved along with advancing socio-economic changes. Quite serious changes in the approach to problems of the location of economic activity took place in the other half of the $20^{\text {th }}$ century with the emergence of globalisation processes. Under the new rules of the economic game, entrepreneurs' location decisions depend on a variety of determinants, both internal conditions of an enterprise and the external possibilities coming from its surroundings. Besides, a characteristic feature of the age of a global economy is the formation of huge international enterprises in the form of corporations of many plants differing in their legal-organisational status, set up to achieve the highest economic efficiency possible at the global scale. The strategies and organisation of those international mega-enterprises, their size, competitive position, level of internationalisation, and the branch in which they operate affect the criteria guiding them in the choice of a location for their activity in the various regions of the world. Hence, old location theories are no longer able to explain location decisions made by this kind of large enterprises, which go for spatial fragmentation of the individual links of the value-added chain in order to enhance efficiency. It is worth emphasising that, in contrast to the classical location theories claiming the location of economic activity to depend exclusively on external conditions and relatively few factors (transport costs, selling prices, the size of the demand), today attention is paid to possible changes in the internal organisation of enterprises and methods of their management as important ways of boosting efficiency and reducing costs (cf. Schamp, 2000: 39), and this also affects the criteria of the choice of a location of economic activity. Hence an explanation of the new patterns of location of today's industrial enterprises, especially those operating at the international scale, is one of the major research problems in socio-economic geography requiring an in-depth look at their internal organisation and the operation strategies adopted. This perspective, in turn, makes it necessary to refer to conceptions worked out in the theory of organisation and management, the theory of enterprises, and industrial economics.

This paper offers an analysis of the location factors of selected factories - affiliates of international corporations, in terms of their strategic decisions of expansion onto markets abroad in the form of foreign direct investment (FDI). For international corporations, the choice of a new place of economic activity is closely connected with global advantages of conducting business at the international scale and with motives for their internationalisation.

\section{ChOice of A LOCATION IN TERMS OF LOCATION FACTORS}

The choice of a location for economic activity is a multi-stage decision-making process that can certainly be included among the highest-ranked decisions, of strategic importance for an enterprise, taken by top-level managers (cf. e.g. Griffin, 2004). In economic geography, the choice of a location as a multi-stage decision process was presented by eg. Dicken and Lloyd (1999) and Kulke (1990) in the form of a hierarchical model (Fig. 1). 
Location preference profile of a company

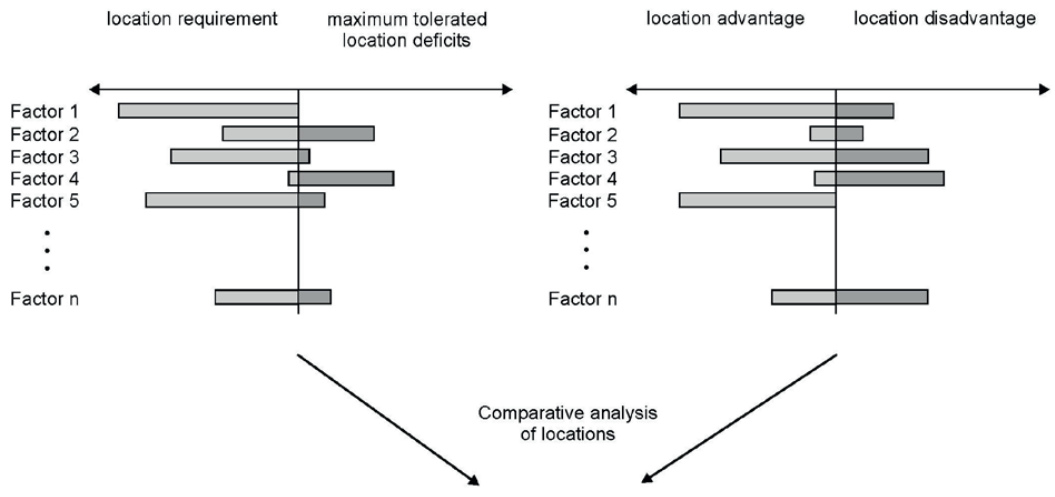

Conditions

in different countries

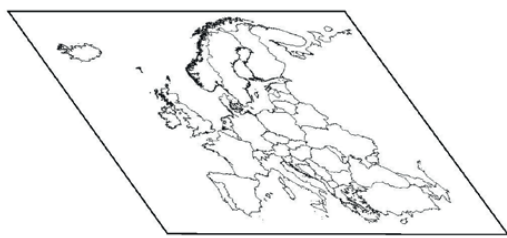

Exclusion of raumen that do not meet the minimum requirement

Location factors selected spatial units

within the appropriate countries

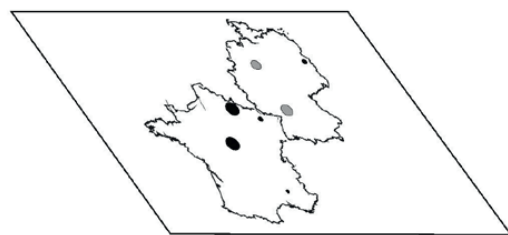

Rational-economic analysis the factor endowment and identification of a limited number

Specific factor leve

of micro sites

in the appropropriate

spatial units

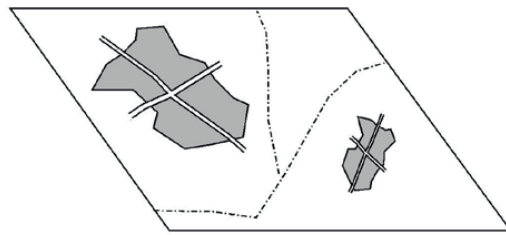

of comparable sites

Location decision

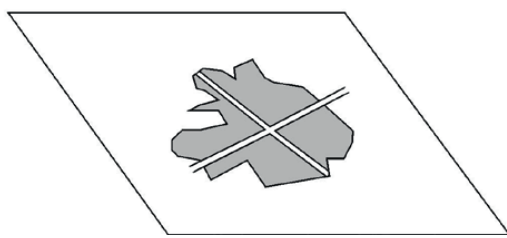

Decision influenced

by the corporate philosophy

Fig. 1. Choice of a location as a hierarchical decision-making process

Source: own compilation on the basis of Kulke, 2009: 39 
It is worth noting in the presented conception of the hierarchical process of the choice of a location, that the choice depends both on factors of production (which make up the profile of an enterprise's requirements) and location factors (which make up the locational profile of the given place). Factors of production are the basic conditions of conducting economic activity; in the classical approach, they include (Mühlbradt, 1999, after Kulke, 2009): labour (understood as a physical and mental activity of the workers employed), land (i.e. the premises occupied and resources of the natural environment, e.g. mineral and energy resources), capital (all goods serving to produce other goods, including e.g. production materials, machines, facilities, tools, buildings), as well as technical knowledge (i.e. the knowledge of products and production processes, the way of organising the production, and management methods). It should be emphasised that today of ever growing importance are qualitative elements of the labour factor, such as human capital, which suggests some desirable features of workers, e.g. flexible competence or creativity. Also knowledge as a factor of production is increasingly seen as a foundation of innovative processes that involve information processing and working out creative solutions to problems. This approach has become a basis of the new stage of economic development and competition, the so-called knowledge-based economy (cf. e.g. Czyż, Chojnicki, 2007; Rachwał, 2013). Porter (1993, after Kulke, 2009: 34) also placedinfrastructure among factors of production, while H.K. Weber (1985, after Kulke, 2009) indicated a complementary group of operational factors of production in which he included institutional services provided by the state and the business environment (e.g. banks, associations).

From the point of view of socio-economic geography, factors of production are analysed primarily in terms of their spatial differences, and in connection with concrete places in space they can be treated as location factors of enterprises. An analysis of location factors in the framework of socio-economic geography is one of the basic research problems connected with the choice of new places for conducting economic activity in geographical space. In both geographical and economic literature, one can find many approaches and definitions of location factors (e.g. Tarski, 1963; Behrens, 1971; Hansmann, 1974; Zajda, 1972; Brücher, 1982; Kortus, 1986; Voppel, 1999; Fierla, Kuciński, 2001; Kulke, 2009: 35-38; Wieloński, 2005; Giese, Mossig, Schröder, 2011; Godlewska-Majkowska, 2013), which also reveal how this research problem has evolved following socio-economic changes. In the classical approach formulated by Weber (1909/1929: 17), “By 'locational factor' we mean an advantage which is gained when an economic activity takes place at a particular point or at several such points rather than elsewhere. An advantage is a saving of cost, i.e. a possibility for the industry to produce at this point a certain product at less cost than elsewhere, to accomplish the entire productive and distributive process of a certain industrial product cheaper at one place than at another". More recent definitions of location factors stress that it is not only place-related economic advantages that decide about the location of an enterprise, but also a favourable effect of all material and non-material factors associated with this place. Thus, generally, it can be stated that location factors mean factors of production located in geographical space which influence decisions about the choice of a location for an industrial plant (or in short: those conditions obtaining in the given place that are decisive for the choice 
of the location). What is significant here is the relation between factors of production as basic conditions of conducting business characterised by stability over a given period of time and wide spatial differences on the one hand, and location factors on the other: a factor of production becomes a location factor through its effect on decisions about the choice of the given location. The decision results, in turn, from locational preferences of an entrepreneur and depends on major internal and external factors of production, such as the kind of products and production processes, including the stage of the product life cycle, external links (e.g. access to raw materials, labour and service providers, or good transport connections) and the strategy of the enterprise. Those relations are presented in Figure 2.

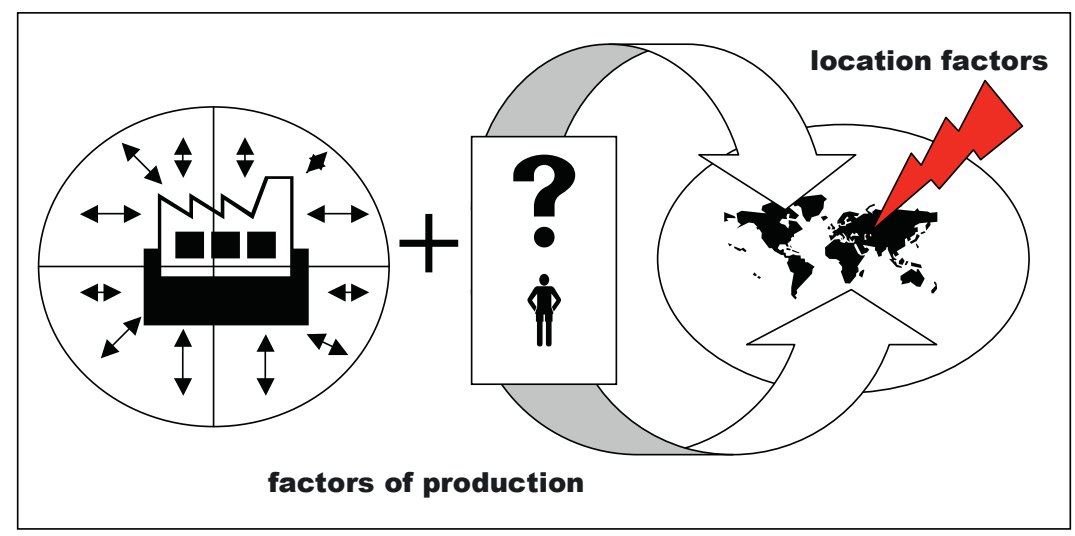

Fig. 2. Choice of a location: factors of production versus location factors

Source: own compilation

It should be stressed that the term "location factors" is often used in the literature interchangeably with "location motives", "conditions of location", or "determinants of location", and Budner (2004), Kuciński (2009) and Godlewska-Majkowska (2013) additionally introduce the notion of "location assets". The differences between those terms are indistinct and rather hard to interpret. The factors/conditions opposition was defined in most explicit terms by Chojnicki and Czyż (2005): "Conditions are those properties found to exist in a place and poorly controllable over short periods, and factors are features active in nature and more controllable". Thus, factors of production understood as basic conditions of conducting business are certain requirements of an enterprise, constant in the given time period, while location factors can be interpreted as a controllable category, i.e. one through which the enterprise can adjust the place of conducting business to those basic conditions by a suitable choice of location.

Apart from the multiplicity of approaches to and definitions of the notion of a location factor, another major issue is a list of factors regarded as decisive in the choice of a place for investment. This is a dynamic list because the importance of location factors tends to change, some gradually lose in significance, while others gain when new circumstances appear. The 
traditional location factors, i.e. those that used to have a strong effect on the choice of a location by enterprises in the past, include: the raw-material base, marketing outlets, transport, the labour force, and agglomeration economies. The impact of those factors on location decisions has changed, although they are still of no minor significance. The new context of impact of those traditional factors can be found in Stryjakiewicz (2009). In turn, Schamp (2000: 39-40) states that the analysis of location factors has been an important research task for many generations of economic geographers and "regionalists" ("Regionalwissenschaftlern") who used empirical results of their studies to construct sets of location factors suitable for various types of industrial plants in the form of guides for managers seeking a quasi-rational choice of a location (e.g. Schmenner, 1982, after Schamp, 2000: 39). In the Polish geographical literature, a synthetic overview of the most important location factors and their changes has been presented by Dziemianowicz (1997), followed by Budner (2004) and Wieloński (2005). Today special weight is ascribed to non-economic factors, and their role has become significant enough for most location analyses to employ a division proposed by Grabowa, Henkel and Hollbach-Grömig (1995) into two categories: hard and soft factors (a wider discussion of this issue can be found in economic geography handbooks, e.g. Wieloński, 2005; Kuciński, 2009; Kulke, 2009). An interesting complement to this division seems to be the addition of two sub-categories of soft factors introduced in DIfU (Deutsches Institut für Urbanistik, 1994, after Kulke, 2009) papers: "business-related" and personal. The former are taken to include the economic climate of the country and town of location, the image of the place where the plant is located, the image of the region, and career opportunities, while the other sub-category covers the dwelling and its surroundings, the quality of the environment, education opportunities, possibilities for recreation and amusement, attractiveness of the region and town, access to high culture, access to pop culture, as well as peace and quiet.

From the point of view of a large international enterprise with an extensive organisationalstructure, worth noting is Kulke's (2009) division of location factors into groups of actors of the economic game in which the enterprise participates (Fig. 3). This type of location analysis is characteristic of a systems approach in which the choice of a location is considered in terms of the structure of the enterprise and its relations with the surroundings (Kulke, 2009: 78).

It should also be observed that of special importance among present-day location factors are institutional ones in the form of various administrative and legal regulations at the regional and national scales (Schamp, 2000; Stachowiak, 2007). This notion was introduced into the literature in 1999 by Stryjakiewicz, who observed that "today location decisions are an effect of negotiations and agreements among various actors of the economic game. Those decisions are determined, on the one hand, by strategies of (often supra-national) firms, and on the other, by institutional patterns of authority at various levels" (Stryjakiewicz, 2009). He gives special economic zones as a typical example of an institutional factor.

The complexity of the process of the choice of a location in a turbulent environment of the global economy gets complicated even more in the case of location decisions taken by large international enterprises with a diversified product offer and an extensive multi-plant structure. 


\begin{tabular}{|l|}
\hline \multicolumn{1}{|c|}{ Company page } \\
\hline - Internal features \\
- Products and product innovations \\
- Processes and process innovations \\
- Business forms (company size, depth range) \\
- Specialization, flexibility \\
- Organization of operational processes \\
.......... \\
- Material infrastructure and logistics system \\
- Transportation, communications, transaction \\
- Demand for suppliers, service providers, buyers \\
- Demand for raw materials, intermediate products \\
- Demand for labor (quantity / quality) \\
......... \\
- Corporate Philosophy \\
- Corporate goals \\
- Decision makers (Optimizer, Satisficer)
\end{tabular}

\begin{tabular}{|l|}
\hline \multicolumn{1}{|c|}{ Demand side } \\
\hline घ Consumer \\
- Income, demand profile, demand volume \\
- Demand behavior, social structures \\
$\ldots \ldots \ldots \ldots . .$. \\
- Operating customer \\
- Industry structures, operating structures \\
- Supply needs, external influence \\
$\ldots \ldots \ldots \ldots \ldots .$. \\
- Supra-regional / national markets \\
- Distance and access other markets \\
- Trade barriers \\
........... \\
\hline
\end{tabular}

\section{Government side / Policy / Planning}

Political conditions

- Economic policy social Policy

- Stability safety

- Operational Policy

- Incentives, deterrence instruments

- Infrastructure

- Location policy

- Land use

- Settlement options

- Commercial areas

Fig. 3. Location factors from the point of view of an enterprise 


\section{Motives FOR AND FACTORS OF THE CHOICE OF A LOCATION BY INVESTORS} AT THE INTERNATIONAL SCALE

The operation, development and growth in efficiency of modern international enterprises are connected with the formation of highly complex organisational-spatial structures, usually multi-dimensional: matrix and tensor ones, characteristic of large corporations, as well as virtual structures made available by new technological possibilities and advanced ICT technologies (e.g. Griffin, 2004, or Kutschker, Schmid, 2005, or Tobolska, 2006). The complexity results from the decomposition by enterprises of Porter's chain of value-added generation and its spatial fragmentation. This means that individual specialised functions of an enterprise, i.e. links in the production chain (e.g. design, research and development, purchase/supply, production and distribution, as well as complementary functions, e.g. management of human or financial resources) are scattered in various places across the world. This strategy of spatial fragmentation is intended to help manufacturing enterprises to find better conditions for the location of individual tasks ensuring them a more efficient accomplishment of their strategic goals and gaining a competitive advantage. The location of direct investments of large international corporations considered as a sequence of production tasks in the chain creating value added (or in the production chain) can also be analysed in a network approach, which means accommodating not only links holding among enterprises, but also their links with the remaining actors of the economic game affecting the generation of value added, both in a vertical and a horizontal system of individual functions. A detailed discussion of these issues can be found in e.g. Schamp (2000), Stryjakiewicz (2005), or Giese, Mossig, Schröder (2011: 149-171).

For socio-economic geographers, an especially interesting research problem is the choice of locations by international corporations in terms of location theory and the location factors of manufacturing activity. Since the operation of international corporations is connected with their expansion onto foreign markets in the form of foreign direct investment (FDI), an explanation of the choice of a location largely focuses on the motives for the expansion abroad and the corresponding location factors, i.e. conditions decisive for the choice of a new place of production. However, in many works the point of departure is motives underlying the search for new places for expansion as preliminary conditions resulting from the appearance of new needs connected with changes in the external surroundings of firms and with their internal changes, i.e. in their organisation or resource-related potential. In motivation theory, motives are incentives stimulating one to action, or causes of behaviour following from needs and determining goals (based on Przybyła, 2003: 267; Griffin, 2004: 518; Colman, 2009: 412). In turn, location factors - as explained in chapter 2 - are place-related conditions deciding about a location. Thus, new locations are supposed to satisfy new needs of enterprises, and those, as has already been emphasised, follow usually from the emergence of new market and institutional determinants and from their competitive position.

The forces driving firms to adopt internationalising and global strategies were presented in detail by Yip (2004, after Gorynia, 2007), who treated them as "forces driving globalisation 
within an industry", or as a "tendency towards international expansion". However, on reflection, they can be regarded as drivers favouring the adoption of global strategies, or simply the motifs. Yip divided them into four groups:

- market drivers (e.g. per capita income, lifestyles, appearance of global customers, growth of regional and global distribution networks, appearance of world brands, and extension of the global reach of the media); it seems that one more driver could be added to this list, namely the advancing convergence of markets;

- cost drivers (e.g. search for economies of scale and scope, accelerating rate of technological innovation, progress in transport, emergence of newly industrialised countries with great productivity potential and low labour costs, increased costs of designing products in relation to the length of their market life);

- government drivers (which could also be called administrative or institutional, e.g. elimination of tariff and non-tariff barriers, setting up economic blocs, growth in the institutionalisation of world trade, limited role of governments - de-nationalisation of many branches, privatisation);

- competitive drivers (e.g. steady growth in the volume of world trade, appearance of new competitors on the global market, appearance of firms "born global", growth in the global international network of interrelations, choice by firms of a global orientation bypassing the domestic scale, an ever growing number of strategic alliances of a global nature); and

- additional drivers (the ICT revolution, globalisation of financial markets, business trips made easier).

A more synthetic approach to the controls of economic activity launched at the international scale was presented by Gorynia (2007, although he also calls them factors):

- the age and stage of the life cycle of an enterprise, a product, a technology;

- the branch to which the firm belongs;

- the firm's home country;

- the situation on the domestic and foreign markets;

- the firm's internationalisation experience; and

- the level of its internationalisation.

The motives for which firms invest abroad have inspired scholars to come up with various theories and paradigms of international manufacturing, e.g. S.H. Hymer's theory of transaction costs, P.J. Buckley and M.C. Casson's internalisation theory, F.C. Knickerbocker's oligopolistic reaction theory, or S.P Magee's appropriability theory. A synthetic survey of those theoretical approaches, also accommodating spatial aspects of the international expansion undertaken, has been made by the present author in her other articles (Tobolska, 2008, 2010). Figuring importantly among them is Vernon's (1966) international theory of the product life cycle, which elucidated the effect of location factors on decisions about the internationalisation of enterprises depending on the stage of the product life cycle (for details see e.g. Dziemianowicz, 1997; Zorska, 1998; Rymarczyk, 2004; Wdowicka, 2005; Wieloński, 2005; Gorynia, 2007; Tobolska, 2008; Bathelt, Glückler, 2003; Kulke, 2009). This conception, however, poorly explains modern locational processes resulting from changes in the regulation of the global economy. The new conditions of the global economy 
have blurred the differences in location factors that used to determine spatial differences in production at individual stages of the product life cycle, so emphasised by the author at the time he constructed his theory. In turn, the conception that still inspires scholars to undertake new location analyses is Dunning's (1980) eclectic theory of international production, the most comprehensive explanation of micro- and macro-economic motives for foreign investment location. It is discussed in detail in many works by geographers and economists (e.g. Dziemianowicz, 1997; Zorska, 1998; Rymarczyk, 2004; Cieślik, 2005; Wdowicka, 2005; Wieloński, 2005; Kutschker, Schmid, 2005; Gorynia, 2007; Tobolska, 2008; Kulke, 2009; Giese, Mossig, Schröder, 2011; Godlewska-Majkowska, 2013), while the OLI (ownership, location, internalisation) paradigm characterising this conception is employed as an analytical tool to account for the behaviour of enterprises at the international scale. The pattern and force of competitive advantages of an enterprise explains alternative modes of action on foreign markets in the form of exports, FDI, or agreements and contracts (cf. Fig. 4).

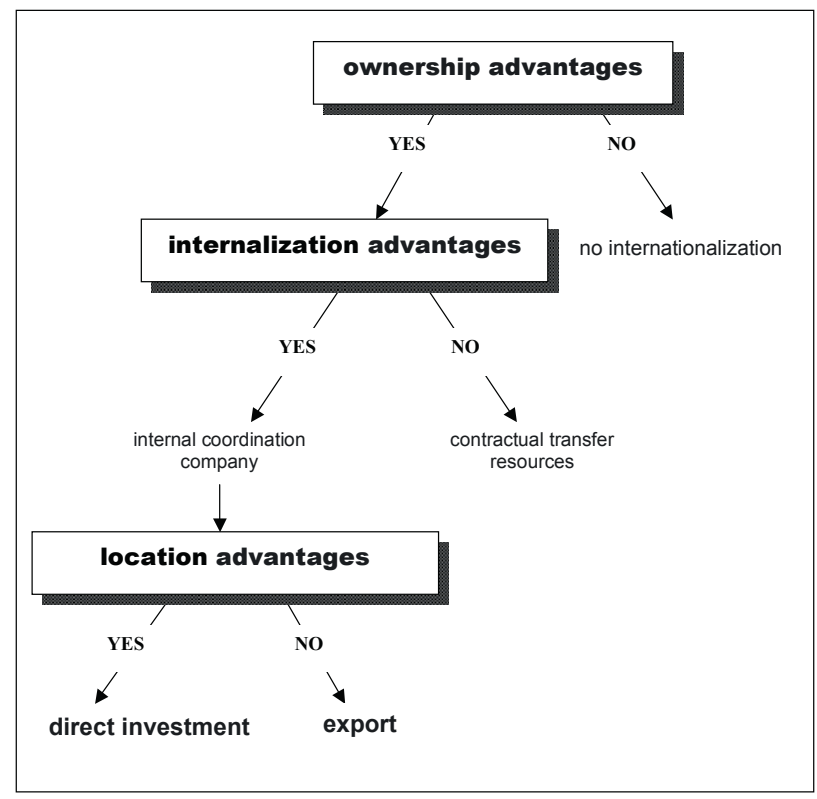

Fig. 4. The OLI paradigm

Source: Kutschker, Schmid, 2005

Although Dunning's conception is often criticised (e.g. it does not explain parallel forms of international expansion employed by enterprises, cf. Giese, Mossig, Schröder, 2011: 58; Schamp, 2000: 48), its especially valuable asset is the use of the classical research apparatus of economic geographers, namely location theory. In order to have international production and expansion abroad in the form of FDI, the enterprise's ownership advantage must be combined with suitable location factors in another country, i.e. with more favourable conditions 
for economic activity than at home. Thus, location factors can be said to determine the spatial distribution of foreign investment and the international production of enterprises.

The motives underlying expansion abroad in the form of FDI have also been classified by many authors in a variety of ways. For example, they can be divided into economic and non-economic (Giese, Mossig, Schröder, 2011: 44), or offensive (i.e. seeking to maximise profits, capture new markets and customers, boost sales) and defensive (e.g. market protection, ensuring supplies - Stoner, Wankel, 1997, after Gorynia, 2007: 59; Giese, Mossig, Schröder, 2011: 44). Still other lists of basicmotives for the internationalisation of enterprises (e.g. Ball and McCulloch, Danils and Radebaugh, Shenkar and Luo) are presented in Gorynia (2007: 59-60) and Kuciński (2009). Especially interesting seems to be the division of motives for expansion abroad proposed by Dunning (1998), involving four different strategies following from the competitive advantages of an enterprise (the OLI paradigm) and determining its forms of expansion onto international markets. According to Dunning, the goal of expansion abroad is to derive concrete advantages from international production (after Gorynia, 2007: 60-62; Bathelt, Glückler, 2003; Kuciński, 2009; Giese, Mossig, Schröder, 2011):

1. Resource-seeking FDI - the goal is to obtain resources unavailable on the domestic market; those can be physical resources, e.g. raw materials, but also human resources, e.g. cheap labour, as well as technological resources, managerial qualifications, or marketing and organisational skills;

2. Market-seeking FDI - the goal is to widen marketing outlets or follow business partners and subcontractors; next, to ensure workplaces in the home country; also, to evade tariff barriers;

3. Efficiency-seeking FDI - the goal is to improve the rationality of the process of production, distribution or marketing by making use of differences in the cost of factors of production among countries as well as economies of scale and scope; and

4. Strategic asset-seeking FDI - the goal is to keep or reinforce one's competitive advantage, firms strive to make use of benefits they derive from having a network of enterprises that operate in a diversified international environment.

Another approach to motives for the choice of a location by international firms was proposed by Domański (2001) and Kulke (2009), who distinguished two basic types of FDI by the motive for its location: (1) seeking to capture or keep a local market (market motives, according to Kulke) and (2) seeking to boost efficiency by cost reductions or access to significant resources (cost-supply-related motives, according to Kulke). Domański stresses that a decided majority of foreign investment in the world belongs to the first group. In turn, cost-related motives involve primarily the lower cost of wages in the host country and concern the most labour-consuming branches. A feature of this type of investment is usually its export orientation.

The motives underlying foreign direct investment also suggest what enterprises expect as to the conditions of conducting an activity in the new location, hence they indicate the potential location factors desired. Generalising, one can state (after Kuciński, 2009 and on the basis of Dunning's conception) that the basic location factors determining FDI flows include 
investment conditions better than in the home country. The number of those factors and their weight vary depending, among other things, on the kind of activity pursued by a corporation, its size, or local conditions. Currently, the location factors most important for investors in the global economy are thought to include (in order of importance, on the basis of UNCTAD's Word Investment Prospects Survey 2009-2011: 44): (1) size of local market, (2) growth of market, (3) presence of suppliers and partners, (4) access to international/regional markets, (4) stable and business-friendly environment, (5) availability of skilled labour and talents, (6) quality of infrastructure, (7) cheap labour, (8) government effectiveness, (9) "follow your competitors", (10) access to natural resources, (11) access to capital market (finance), and (12) incentives. As follows from these data, the top priority with foreign investors is demand drivers connected with marketing outlets, but a high position in this ranking is also occupied by access to skilled labour, higher than cheap labour, so far considered one of the basic location factors of foreign investment (cf. e.g. Ruppert, 1988, after Kulke, 2009: 89; Wieloński, 2005: 35 ). Worth noting is the great weight assigned to the presence of suppliers and business partners, which shows vertical integration to be of much importance in the framework of spatial fragmentation.

A synthetic survey of the significance of location factors for international corporations making foreign direct investment is presented in Schiller et al. (2013, after GodlewskaMajkowska, 2013, Fig. 5).

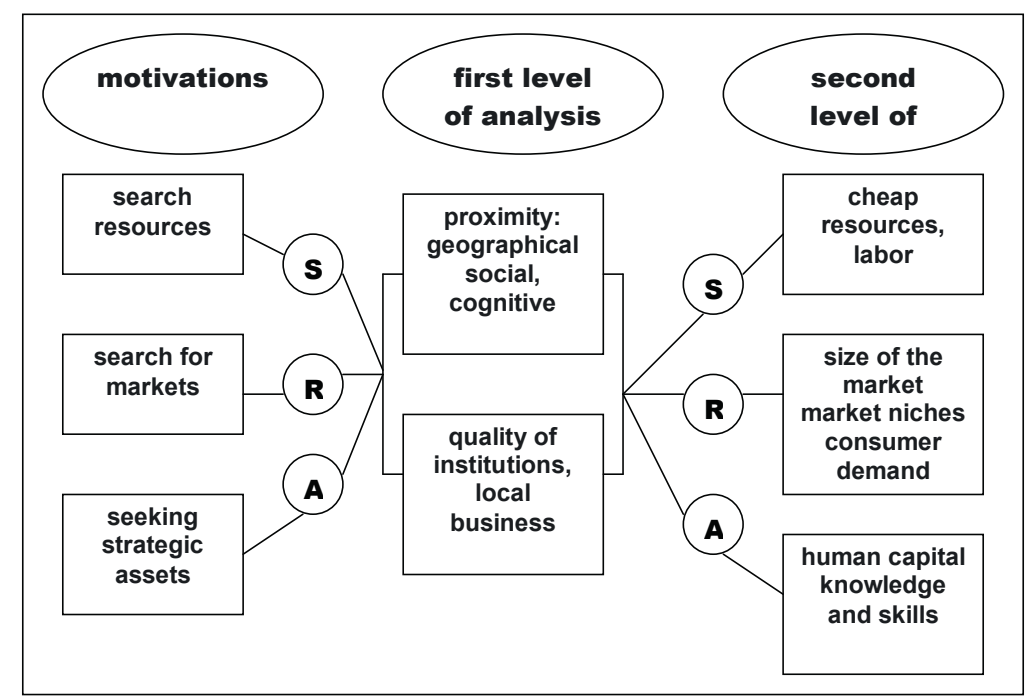

Fig. 5. Motives and factors underlying location decisions

Source: Godlewska-Majkowska, 2013: 58, after Schiller, Revilla Diez, Zvirgzde, 2013

Those authors divide the factors into two main groups: economic and institutional, which they consider at two levels: (1) one involving an analysis of institutional factors, such as legal rules for conducting economic activity in the given country, the socio-cultural 
closeness of the host country, or its geographical nearness, and (2) another, involving an analysis of economic factors similar to the basic motives for launching an activity abroad presented by Dunning, i.e. a search for resources, markets or strategic assets. In their conception, if the first-level factors are assessed as unfavourable, the remaining factors are not even considered, and direct investment may not come into effect at all, although there can be exceptional situations when the second-level factors outweigh barriers at the first level. A similar hierarchy of location decisions was also proposed by Kulke (2009: 244-245), who defined minimum preliminary requirements for undertaking an economic activity abroad (among which he included basic transport infrastructure, basic legal regulations concerning foreign investment, and political stability).

To verify those conceptions, the present author made her own empirical study of the location of selected factories - affiliates of international corporations - in Poland. Its preliminary results were published in 2010 .

Location factors of Swedwood Poland, Volkswagen Motor Poland, AND EXIDE TEChNOlogies In POLAND VIEWED IN TERMS

OF THE STRATEGIC ORIENTATION OF THE CONCERNS

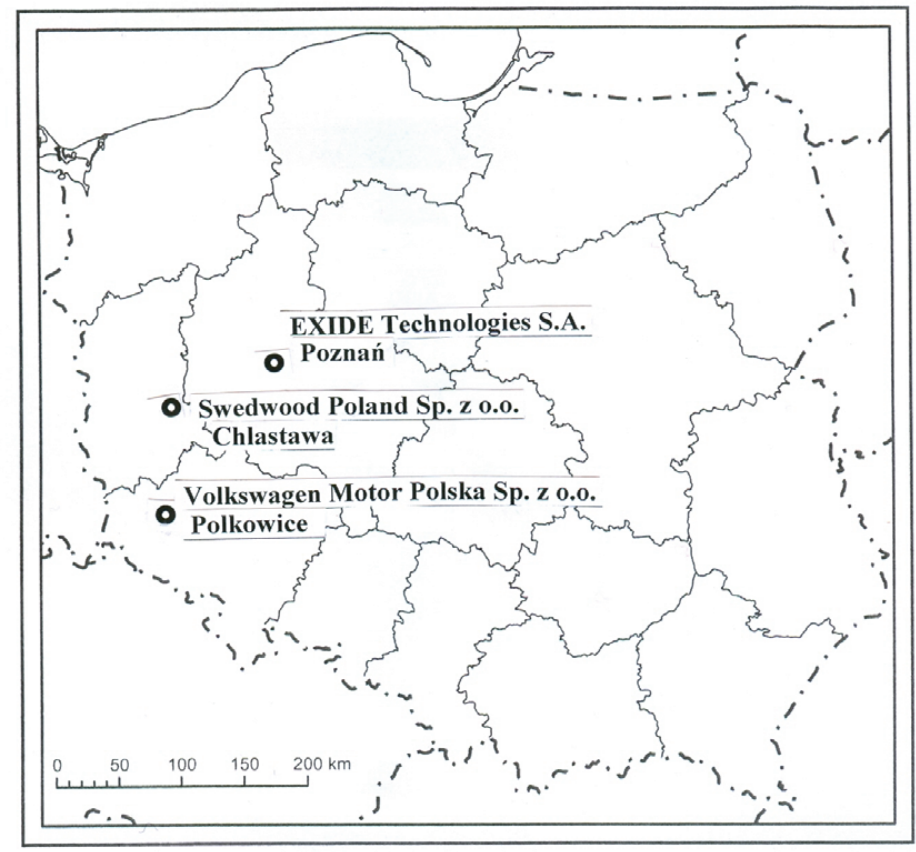

Fig. 6. Location of Swedwood Poland, Volkswagen Motor Poland and EXIDE Technologies plants in Poland's administrative system

Source: own compilation 
To illustrate motives for and location factors of foreign direct investment in Poland in the first decade of the new century, an empirical study was conducted in three selected factories (cf. Tobolska, 2011, Fig. 6):

1. Swedwood Poland Ltd. - a factory located in a small village of Chlastawa near Zbąszynek, in Lubuska Land, an affiliate of the international concern Swedwood International Ltd., which, in turn, belongs to the Swedish IKEA holding. The factory is a greenfield investment built in 1999 to produce furniture exclusively for the network of IKEA shops.

2. Volkswagen Motor Poland Ltd. - a factory located at Polkowice, a subzone of the Legnica Special Economic Zone, an affiliate of the German concern Volkswagen AG. It produces compression-ignition engines for many models of the concern's cars manufactured in various locations across the world. The factory was built in 2000.

3. EXIDE Technologies Co., until 2008 Centra Co. - a factory located in Poznań, taken over under capital privatisation in 1995 by the American strategic investor EXIDE Technologies. In Poznań the concern manufactures accumulators for lorries and buses, agricultural vehicles, construction vehicles, and automobiles.

In the first stage of the research procedure seeking to establish location factors of the selected affiliates of international concerns in Poland, questionnaire interviews were conducted with representatives of their management who participated in the decision-making processes concerning the location in Poland. The questionnaire offered a list of 29 location factors most frequently given in the literature to grade them on a five-point scale: from 5 (very important) to 1 (least important). There was also " 0 " to be chosen when the given factor was not taken into consideration at all when locating the investment. This type of analysis of potential location factors allowed their quantitative assessment (Tab. 1).

Tab. 1. Assessment of location factors of Swedwood Poland at Chlastawa, Volkswagen Motor Poland at Polkowice, and EXIDE Technologies in Poznań by representatives of their management

\begin{tabular}{|r|l|c|c|c|}
\hline No. & \multicolumn{1}{|c|}{ LOCATION FACTORS } & Swedwood & VW MP & EXIDE \\
\hline \multicolumn{5}{|c|}{ MARKET } \\
\hline 1. & gaining and maintaining market & 0 & 4 & 5 \\
\hline 2. & follow the competition & 0 & 1 & 4 \\
\hline 3. & $\begin{array}{l}\text { absorptive capacity of the local market and } \\
\text { domestic (demand for products factory) }\end{array}$ & 1 & 4 & 5 \\
\hline 4. & good access to other European markets & 5 & 2 & 5 \\
\hline \multicolumn{5}{|c|}{ COST-RELATED } \\
\hline 5. & 4 & 5 & 5 \\
\hline 6. & lower labor costs & 4 & 5 & 5 \\
\hline 7. & lower taxes & 5 & 5 & 0 \\
\hline 8. & the possibility of a favorable land & 5 & 5 & 0 \\
\hline 9. & $\begin{array}{l}\text { investment incentives and favorable } \\
\text { regulatory }\end{array}$ & 4 & 4 & 3 \\
\hline 10. & technical infrastructure & 5 & 4 & 5 \\
\hline 11. & proximity to the western boundary & 5 & 5 & 5 \\
\hline
\end{tabular}




\begin{tabular}{|c|c|c|c|c|}
\hline 12. & $\begin{array}{l}\text { the possibility of using rail logistics } \\
\text { companies }\end{array}$ & 5 & 4 & 3 \\
\hline 13. & $\begin{array}{l}\text { proximity to the motorway (real plans for } \\
\text { its construction) }\end{array}$ & 2 & 4 & 4 \\
\hline 14. & good availability of air & 0 & 2 & 3 \\
\hline 15. & liberalne wymagania ekologiczne & 2 & 1 & 0 \\
\hline \multicolumn{5}{|c|}{ RESOURCE-RELATED } \\
\hline 16. & availability of skilled workers & 4 & 5 & 5 \\
\hline 17. & $\begin{array}{l}\text { good performance and quality of work of } \\
\text { Polish workers }\end{array}$ & 5 & 5 & 3 \\
\hline 18. & $\begin{array}{l}\text { proximity to raw materials and semi- } \\
\text { finished }\end{array}$ & 5 & 0 & 5 \\
\hline 19 & proximity to suppliers and subcontractors & 5 & 1 & 5 \\
\hline 20 & $\begin{array}{l}\text { availability of maintenance services for the } \\
\text { company and the business environment }\end{array}$ & 3 & 3 & 4 \\
\hline \multicolumn{5}{|c|}{ SOFT } \\
\hline 21. & $\begin{array}{l}\text { positive attitudes of Polish workers to } \\
\text { work }\end{array}$ & 5 & 4 & 5 \\
\hline 22. & $\begin{array}{l}\text { initiative and cooperation of local } \\
\text { authorities }\end{array}$ & 5 & 4 & 4 \\
\hline 23. & quality of service in the office & 5 & 4 & 1 \\
\hline 24. & favor of the local community & 5 & 4 & 4 \\
\hline 25. & $\begin{array}{l}\text { the positive experience of other companies } \\
\text { investing in the region }\end{array}$ & 5 & 3 & 3 \\
\hline 26. & $\begin{array}{l}\text { availability of information about the } \\
\text { region }\end{array}$ & 4 & 4 & 5 \\
\hline 27. & level of socio-economic development & 3 & 5 & 5 \\
\hline 28. & good image of the region & 3 & 5 & 5 \\
\hline 29. & $\begin{array}{l}\text { attractiveness of the environment and } \\
\text { landscape }\end{array}$ & 1 & 3 & 3 \\
\hline
\end{tabular}

Source: own compilation based on empirical study

The next stage of the analysis involved putting the listed factors into four groups reflecting the chief motives for undertaking expansion abroad, according to the division proposed by Domański and Kulke (cf. chapter 3): (1) market factors, (2) cost-related factors, (3) resource-related factors, and (4) "soft" factors. The first three groups were taken to embrace "hard" factors, while the fourth included non-economic factors which play a significant role in location decisions today. Next the relative mean weight of the points obtained for all factors in one group was determined. The weight was calculated as the percentage of the sum of points obtained in relation to the possible maximum, i.e. 5 multiplied by the number of factors in the given group. The relative weights of the individual groups of factors for all the three enterprises separately served to plot their location profiles, i.e. diagrammatic presentations of the weight of each group of factors for the analysed plants (Fig. 7). 


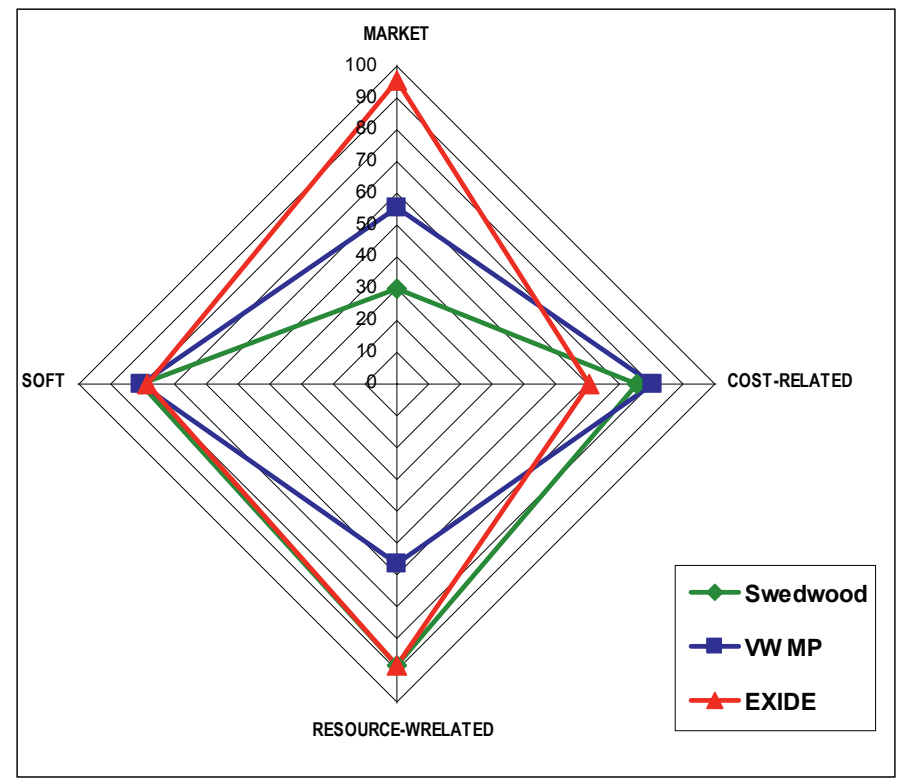

Fig. 7. Location profiles of the selected international corporations by weight of individual groups of factors

Source: own compilation

The following were the most important location factors for each factory:

1) For Swedwood Poland at Chlastawa, the most important turned out to be resource/ supply-related factors ( $88 \%$ importance) and soft factors $(80 \%)$. What decided the Swedwood location were primarily such resource-related factors as nearness to raw materials and semi-products, suppliers and subcontractors, and the quality of labour of Polish workers. In the second most important group that played a role in deciding about the Chlastawa location were soft factors, especially very good cooperation with the local authorities, a favourable reception by the local community, and the attitude of Polish workers towards their duties. Third place went to cost-related factors, which included tax concessions (the factory was exempted from local taxes for ten years by a Commune Council resolution), the possibility of a cheap purchase of the premises, physical infrastructure (on the initiative of the commune authorities, the lot intended for the factory had been equipped with water-supply, sanitation and other facilities), access to the railway network (a siding had connected the lot with the main track), and the closeness of the western border of Poland. The last factor is connected with the group of market ones, i.e. good access to other European markets, of great importance for Swedwood because nearly all of its output is intended for export, to the network of IKEA shops, in particular to Germany. Apart from this, market factors such as capturing or keeping the market did not figure prominently in the location of the new Swedwood factory at Chlastawa. The top two cost factors, i.e. labour costs and general operating costs of the plant, did not obtain the highest weight in the opinion of the Swedwood management, which 
is connected with their experience in running factories in other countries with even lower labour and operating costs, e.g. Ukraine or Russia.

2) For the Volkswagen concern, the most important factors underlying the location of the factory at Polkowice were those from two groups: cost-related and soft ones (although in the former group there were more that obtained the highest grade, i.e. 5). The most important among cost factors were lower labour and operating costs of the plant, which is connected with a favourable location in a special economic zone and the possibility of making use of its privileges, i.e. tax reductions and the cost of land. Among soft factors, all those listed in the questionnaire turned out to be significant and got at least 4 points, the most important ( 5 points) being a good image of the region and its development level. The highest grade, 5, was also given to two factors from the resource-related group: availability of skilled workers and quality of labour; the remaining factors - sources of supply and resources - played a minor role in the decision about the location of the VW factory. Market factors were of no great significance either, although two of them, viz. keeping and capturing the market as well as demand on the domestic market, got a fairly high grade, 4 .

3) What decided the purchase of a controlling interest in the Centra factory of batteries and accumulators in Poznań by the EXIDE Technologies concern were primarily market factors: capturing and keeping marketing outlets, demand for the firm's products on the Polish market, good access to other European markets, and the 'follow your competitors' motive. Second place went to resource-related ones, such as nearness of raw materials and semi-products, nearness of suppliers and subcontractors, and availability of skilled labour. Those factors were connected with the way in which this American concern entered the Polish market: it used local infrastructure (local from the perspective of the concern) by purchasing a ready-made factory from the same branch, with its skilled workforce, with its channels of distribution and supply of raw materials for production worked out during the several decades of operation, and especially with the well-known Centra brand and a strong position on the Polish and former COMECON markets. Next came soft factors, such as availability of information about the region, its socio-economic development and good image; this group of factors, while not the most important in the EXIDE location decision, had a weight that did not depart much from that given to it by the remaining two affiliates. Relatively the smallest role in the decision was played by cost-related factors, although four of them obtained maximum points, 5: labour costs and operating costs, level of infrastructure (which involved a reduction in investment costs), and nearness of the western border (connected with the cost of access to the western markets).

To sum up the analysis of the effect of 29 factors on the location of the selected affiliates of international concerns, it is worth noting that the factor common to all three corporations that obtained the highest weight, 5, was the nearness of the western border (a total of 15 points). Only slightly smaller weight in the general assessment was given to three cost-related factors: lower labour costs, lower operating costs in the given region, and its level of physical infrastructure (which for the investor largely means savings on outlays for the construction of such necessary infrastructure), as well as one resource-related factor: availability of skilled workers. All decision-makers also assigned the highest weight to the positive 
attitude of their Polish staff towards work. It seems that the last factor was especially stressed by the investors in the context of their experiences in other parts of the world where they employ local labour too; against this background, Polish workers enjoy a favourable opinion.

The above common factors that were assigned the highest significance can therefore be regarded as the main assets of the western region of Poland in which the three factories are located.

\section{CONCLUSIONS}

As follows from the analysis of the results of the empirical study, the location factors indicated by the managerial staff of the enterprises reflect fairly well the motives, and hence the strategies, of the international concerns underlying their expansion onto the Polish market. In each of the three cases, the choice of the location for a new factory by the parent concern was intended to make use of their ownership and internalisation advantages, which according to Dunning's conception is a basic condition of the internationalisation of enterprises. An additional and necessary condition for expansion in the form of FDI is finding favourable conditions in space, i.e. location factors, which in the three cases has led to the location of factories in the western part of Poland. The location factors indicated by all three enterprises made it possible to identify their chief motives - incentives - to adopt an internationalisation strategy in the form of FDI. Thus, the factors that carried the greatest weight with the Swedwood corporation were resource-related ones, which shows that a major motive for its expansion into western Poland was gaining access to some resources important for its operation. Hence its strategy of entering the Polish market can be described in Dunning's terminology as resource-seeking. In turn, for the Volkswagen Motor factory, the most important motives proved to be cost-related ones, as indicated by the highest weight assigned to cost factors; as in the previous case, on this basis its strategy can be termed efficiency-seeking. The investment of the EXIDE concern in Poznan and its choice of mostly market-related location factors allows its strategy to be identified as market-seeking (Fig. 8).

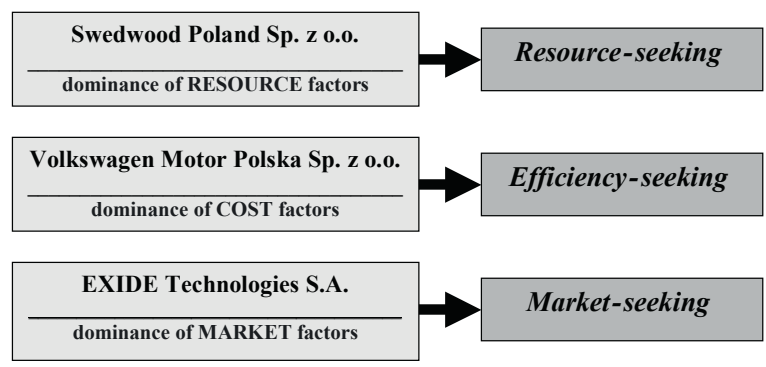

Fig. 8. Location factors seen against motives and strategies of expansion onto international markets on the example of the selected factories

Source: own compilation on the basis of an empirical study 
The presented analysis of location factors in the framework of the conception of location motives reveals some new ways of establishing expansion strategies of international corporations. It is worth emphasising, however, that the above results were obtained in specified conditions held in the given place and time, and need not repeat themselves in other circumstances for the same corporation. In a turbulent environment of the global economy, changes occur fairly spontaneously, and in order to survive enterprises must accommodate them in their strategies.

\section{References}

Bathelt, H., Glückler, J. (2003). Wirtschaftsgeographie. Ökonomische Beziehungen in räumlicher Perspektive. Stuttgart: Verlag Eugen Ulmer.

Behrens, C. (1971). Allgemeine Standortsbestimmungslehre. Opladen: Verlag.

Brücher, W. (1982). Industriegeographie. Braunschweig: Westermann.

Budner, W. (2004). Lokalizacja przedsiębiorstw. Aspekty ekonomiczne, przestrzenne i środowiskowe. Poznań: Wydawnictwo Akademii Ekonomicznej w Poznaniu.

Chojnicki, Z., Czyż, T. (2005). Rozwój społeczno-gospodarczy w ujęciu regionalnym. Biuletyn Komitetu Przestrzennego Zagospodarowania PAN, 219. Warszawa.

Chojnicki, Z., Czyż, T. (2007). Rola kapitału ludzkiego w kształtowaniu gospodarki opartej na wiedzy w Polsce. Przeglad Geograficzny, 79(3-4), 423-428.

Colman, A.M. (2009). Stownik psychologii. Warszawa: Wydawnictwo Naukowe PWN.

Cieślik, A. (2005). Geografia inwestycji zagranicznych. Warszawa: Wydawnictwo Uniwersytetu Warszawskiego.

Deutsches Institut für Urbanistik. (1994). Standortbedingungen in Deutschland und Bedeutung von Standortfaktoren. Berlin.

Dicken, P., Lloyd, P.E. (1999). Standort und Raum - Theoretische Perspektiven der Wirtschaftsgeographie. Stuttgart: Ulmer.

Domański, B. (2001). Kapitał zagraniczny w przemyśle Polski. Prawidłowości rozmieszczenia, uwarunkowania i skutki. Kraków: Uniwersytet Jagielloński, Instytut Geografii i Gospodarki Przestrzennej.

Dziemianowicz, W. (1997). Kapitał zagraniczny a rozwój regionalny i lokalny w Polsce. Studia Regionalne i Lokalne, 21(54). Warszawa: Uniwersytet Warszawski, Europejski Instytut Rozwoju Regionalnego i Lokalnego.

Dunning, J.H. (1980). Toward an Eclectic Theory of International Production: Some Empirical Tests. Journal of International Business Studies, 11(1).

Dunning, J.H. (1998). Location and the Multinational Enterprise: A Neglected Factor? Journal of International Business Studies, 29(1).

Fierla, I., Kuciński, K. (2001). Lokalizacja przedsiębiorstwa a konkurencyjność. Materiały i Prace Instytutu Funkcjonowania Gospodarki Narodowej, LXXVI, p. 65. Warszawa: SGH.

Giese, E., Mossig, I., Schröder, H. (2011). Globalisierung der Wirtschaft. Eine wirtschaftsgeographische Einführung. Paderborn: Verlag Schöingh.

Godlewska-Majkowska, H. (2013). Lokalizacja przedsiębiorstwa w gospodarce globalnej. Warszawa: Difin.

Gorynia, M. (2007). Strategie zagranicznej ekspansji przedsiębiorstw. Warszawa: Polskie Wydawnictwo Ekonomiczne.

Grabow, B., Henckel, D., Hollbach-Grömig, B. (1995). Weiche Standortfaktoren. Stuttgart: Schriften des Deutschen Institut für Urbanistik. 
Griffin, R.W. (2004). Podstawy zarzadzania organizacjami. Warszawa: Wydawnictwo Naukowe PWN.

Hansmann, K. (1974). Entscheidungsmodelle zur Standortplannung der Industrieunternehmen. Wiesbaden: Verlag.

Kortus, B. (1986). Wstęp do geografii przemystu. Warszawa: PWN.

Kuciński, K. (red.) (2009). Geografia ekonomiczna. Kraków: Oficyna Wydawnicza Wolters Kluwer Business.

Kulke, E. (1990). Faktoren industrieller Standortwahl - theoretische Ansätze und empirische Ergebnisse. Geographie und Schule, 12 H.63, 2-8.

Kulke, E. (2009). Wirtschaftsgeographie. Pederborn: Schöningh Verlag.

Kutschker, M., Schmid, S. (2005). Internationales Management. München-Wien: Oldenbourg Verlag.

Launhardt, C.W. (1882). Die Bestimmung des Zweckmässigsten Standortes einer Gewerblichen Anlage. Zeitschrift des Vereines Deutscher Ingenieure, 26(3), 105-116.

Mühlbradt, F.W. (1999). Wirtschaftslexikon. Berlin: Cornelsen.

Porter, M.E. (1993). Nationale Wettbewerbs Vorteile. Wien: Ueberreuter.

Przybyła, M. (ed.) (2003). Organizacja i zarzadzanie. Podstawy wiedzy menedżerskiej. Wrocław: Wydawnictwo Akademii Ekonomicznej im. Oskara Langego.

Rachwał, T. (2013). Rola przedsiębiorstw przemysłowych w rozwoju gospodarki opartej na wiedzy. Prace Komisji Geografii Przemystu Polskiego Towarzystwa Geograficznego, 21, 189-211.

Ruppert, R. (1988). Die portugiesische Industrie. In: W. Ritter, R. Ruppert, K.L. Storck (eds.), Portugal im Aufbruch? Nürnberg: Selbsverlag.

Rymarczyk, J. (2004). Internacjonalizacja i globalizacja przedsiębiorstw. Warszawa: PWE.

Schamp, E.W. (2000). Vernetzte Produktion. Industriegeographie aus institutioneller Perspektive. Darmstadt: Wissenchaftliche Buchgesellschaft.

Schiller, D., Revilla Diez, J., Zvirgzde, D. (2013). Location choices of multinational companies in transition economies. A Literature Review, WP2/05 Search Working Paper.

Schmenner, P.W. (1982). Making Business Location Decisions. Englewood Cliffs: Prentice Hall.

Stachowiak, K. (2007). Instytucjonalne uwarunkowania bezpośrednich inwestycji zagranicznych w Polsce. Poznań: Bogucki Wydawnictwo Naukowe.

Stoner, J.A.F., Wankel, C. (1997). Kierowanie. Warszawa: PWE.

Stryjakiewicz, T. (1999). Adaptacja przestrzenna przemystu $w$ Polsce $w$ warunkach transformacji. Poznań: Wydawnictwo Naukowe UAM.

Stryjakiewicz, T. (ed.) (2005). Impact of foreign investors on regional and local development: the case of GlaxoSmithKline Pharmaceuticals S.A. in Poznań. Poznań: Bogucki Wydawnictwo Naukowe.

Stryjakiewicz, T. (2009). Nowe spojrzenie na czynniki lokalizacji działalności gospodarczej. In: I. Jażewicz (ed.), Wspótczesne problemy przemian strukturalnych przestrzeni geograficznej. Słupsk: Wydawnictwo Naukowe Akademii Pomorskiej, 94-102.

Tarski, I. (1963). Transport jako czynnik lokalizacji produkcji. Warszawa: PWE.

Tobolska, A. (2006). Strategie globalne a nowe formy organizacji przedsiębiorstw transnarodowych. In: Z. Zioło, T. Rachwał (eds.), Rola przedsiębiorczości w podnoszeniu konkurencyjności społeczeństwa i gospodarki. Przedsiębiorczość - Edukacja, 2, 125-143.

Tobolska, A. (2008). Przestrzenne aspekty ekspansji zagranicznej korporacji międzynarodowych w koncepcjach internacjonalizacji. In: T. Czyż, T. Stryjakiewicz, P. Churski (eds.), Nowe kierunki i metody w analizie regionalnej. Biuletyn IGS-E iGP, UAM, Seria Rozwój Regionalny i Polityka Regionalna, nr 3. Poznań: Bogucki Wydawnictwo Naukowe, 89-113.

Tobolska, A. (2010). Koncepcje teoretyczne wyjaśniające zachowania korporacji międzynarodowych wymiar przestrzenny. Ekonomista, 2/2010. Warszawa: Wydawnictwo KeyText, 243-258.

Tobolska, A. (2011). Czynniki lokalizacji fabryk wybranych korporacji międzynarodowych w Polsce. In: L. Mierzejewska, M. Wdowicka (eds.), Problemy rozwoju lokalnego i regionalnego na poczatku XXI wieku. Biuletyn Instytutu Geografii Społeczno- Ekonomicznej i Gospodarki Przestrzennej 
UAM, Seria Rozwój Regionalny i Polityka Regionalna, nr 15. Poznań: Bogucki Wydawnictwo Naukowe, 55-67.

UNCTAD. (2009). Word Investment Prospects Survey 2009-2011. United Nations, New York and Geneva. Retrieved from unctad.org/en/docs/diaeia20098_en.pdf.

Vernon, R. (1966). International Trade and International Investment in the Product Cycle. Quarterly Journal of Economics, 2.

Voppel, G. (1999). Wirtschaftsgeographie - Räumliche Ordnung der Weltwirtschaft unter marktwirtschaftlichen Bedingungn. Stuttgart: Teubner, p. 39.

Weber, A. (1909). Theory of the Location of Industries. Chicago: The University of Chicago Press, 1929. Retrieved from archive.org/stream/alfredweberstheo00webe/alfredweberstheo00webe djvu.txt.

Weber, A. (1909). Über den Standort derIndustrie. 1. Teil. Reine Theorie des Standortes. Tübingen.

Weber, H.K. (1985). Industriebetriebslehre. Berlin-Heidelberg-New York-Tokyo: Springer.

Wdowicka, M. (2005). Bezpośrednie inwestycje zagraniczne i inwestycje samorzadowe w aglomeracji poznańskiej w okresie transformacji ustrojowej. Poznań: Bogucki Wydawnictwo Naukowe.

Wieloński, A. (2005). Geografia przemystu. Warszawa: Wydawnictwo Uniwersytetu Warszawskiego, $33-38$.

Yip, G.S. (2004). Strategia globalna. Warszawa: PWE.

Zajda, Z. (1972). Ekonomiczne problemy lokalizacji przemysłowej. In: K. Secomski (ed.), Elementy teorii planowania przestrzennego. Warszawa: Wydawnictwo Naukowe PWN.

Zorska, A. (1998). Ku globalizacji? Przemiany w korporacjach transnarodowych $i$ w gospodarce światowej. Warszawa: Wydawnictwo Naukowe PWN.

Anna Tobolska, Ph.D., Adam Mickiewicz University, Poznań, Poland, Institute ofSocio-Economic Geography and Spatial Management.Dr Anna Tobolska is an adjunct professor in the Institute of SocioEconomic Geography and Spatial Management in the Faculty of Geographical and Geological Sciences of Adam Mickiewicz University in Poznań. Her research interests focus mainly on issues in industrial geography, like changes in industrial structures at various spatial scales as well as local and regional effects of the location of industrial enterprises, especially those belonging to international corporations. Her output embraces dozens of publications, including the books Zmiany własnościowe i organizacyjno-ekonomiczne $w$ wybranych duzych przedsiębiorstwach przemystowych Poznania $w$ okresie transformacji (Ownership and organisational-economic changes in selected large industrial enterprises of Poznań during the transformation period) (2004) and Miejsce inwestora zagranicznego $w$ przestrzeni lokalnej i regionalnej na przyktadzie Swedwood w Chlastawie (Place of the foreign investor in the local and regional space: The case of Swedwood at Chlastawa) (2010). She is also the editor of the monograph Pleszew - Struktura społeczno-gospodarcza miasta i gminy w ujęciu przestrzennym (Pleszew: The socio-economic structure of the town and commune in a spatial approach) (2011) and co-author of the guide Geografia społeczno-gospodarcza (Socio-economic geography) (2013). She conducts classes with Geography and Spatial Management students, including lectures on industrial geography, methods of spatial analysis, and the theory of organisation and management. She has also performed responsible organisational functions in the Faculty: in years 2008-2012 she was the Institute's deputy director for didactic matters, and at present she is Deputy Dean for extramural studies and the implementation of the National Qualifications Framework for Higher Education.

\section{Adres/address:}

Adam Mickiewicz University

Institute of Socio-Economic Geography and Spatial Management

ul. Dzięgielowa 27, 61-680 Poznań, Poland

e-mail: juli@amu.edu.pl 